\title{
User Involvement, Procurement Practices and Implementation of Building Construction Projects in the Kenyan Judiciary
}

\author{
John F Okello(Phd Student) ${ }^{* 1} \quad$ Omondi Bowa(Phd $)^{2} \quad$ Joash Migotsi(Phd $)^{2}$ \\ 1.Department of Management Science and Project Planning, University of Nairobi,P.O.Box 30197-00100, \\ Nairobi, Kenya \\ 2.Faculty of Education,University of Nairobi, P.O.Box 30197-00100, Nairobi, Kenya
}

\begin{abstract}
Kenyan population increased from 20 million in 1985 to approximately 47.6 million in 2019 and with it, demand for justice also increased yet the growth did not come with improved Judiciary infrastructure. This attracted the World Bank through the Judicial Performance Improvement Project (JPIP) to fund 30 major court construction projects while the Kenyan Government also funded another 33 such projects from 2013. However, by January, 2020 ,only 10 projects had been completed and successfully handed over with all the 63 projects being out of the planned time and with variation on the original scope of works. This gave rise to this study that aimed to evaluate the influence of user involvement on implementation of building construction projects in the Kenyan judiciary as moderated with the procurement practices. The study was based on general systems theory. Pragmatism paradigm and convergent parallel mixed research design was adopted and proportionate stratified sampling was used to select a population of 234 consisting of judiciary staff, construction staff and consultants .Primary data was collected through use of questionnaires, interviews and document content analysis. Reliability was tested using Cronbach's Alpha while data was analyzed using descriptive statistics which included measures of central tendency. Qualitative data was subjected to thematic analysis to triangulate results derived from quantitative data. Inferential statistics was analyzed by correlation, simple linear regression and multiple regression analysis. Two hypotheses were tested to establish whether there were significant relationships between project delivery attributes and implementation of building construction projects in the Kenyan Judiciary, namely $1 . \mathrm{H}_{0}$ : User Involvement has no significant relationship with implementation of construction projects in the Kenyan Judiciary and 2. $\mathrm{H}_{0}$ : There is a significant moderating influence of procurement practices on the relationship between user involvement and implementation of building construction projects in the Kenyan Judiciary. The findings were that there was a significant influence of user involvement on the implementation of construction projects in the Kenyan Judiciary and that procurement practices significantly moderated the relationship between user involvement and implementation of building construction projects in the Kenyan Judiciary. The slope coefficient was significant when $\mathrm{p} \leq 0.05$. The findings of the study will be beneficial to policy makers, project managers in public and private sectors and scholars regarding project delivery attributes on implementation of building construction projects.
\end{abstract}

Keywords: User involvement, Procurement Practices and Implementation of Building Construction Projects.

DOI: $10.7176 / \mathrm{EJBM} / 13-18-12$

Publication date:September $30^{\text {th }} 2021$

\section{Introduction}

Project Implementation is an area of great concern to all stakeholders due to the immense resources committed to projects. Project Implementation (Project Performance) is the expectation of all stakeholders concerned. Even though, there are different definitions of Project implementation, (Muller, Geraldi and Turner, 2012) perceived Project performance to mimic project success. Existing statistics on project implementation has recorded $90 \%$ failure rate of major construction projects (Deloitte, 2017). In United Kingdom, construction projects are characterized by unreliable delivery procedures due to budget and time overruns (Ochieng and Price, 2009). The average World Bank project failure rate is $50 \%$ in Africa (Ika, Diall and Thuillier,2011). There is time and budget overruns in at least $90 \%$ and $28 \%$ in Africa respectively. This is lower than Kenyan average which is $47 \%$ for cost overruns and slightly higher than $87 \%$ for time overruns (Deloitte, 2017).

\subsection{Statement of the problem}

Kenyan population increased from 20 million in 1985 to approximately 47.6 million in 2019 and with it, demand for justice also increased yet the growth did not come with improved Judiciary infrastructure. This attracted the World Bank through the Judicial Performance Improvement Project (JPIP) to fund 30 major court construction projects while the Kenyan Government also funded another 33 such projects from 2013. However, by January, 2020 ,only 10 projects had been completed and successfully handed over with all the 63 projects being out of the planned time and with variation on the original scope of works. Delay in delivery of the court building contracts amounts to delayed justice as the court building constructions are meant to reduce the distance to court and thus take justice closer to the people. This study was thus carried out with the aim of evaluating the influence of user 
involvement and the moderating effects of procurement practices on the implementation of the building construction projects in the Kenyan judiciary.

The Delivery of a project can be compared to a delivery of a manufactured good from one point to the other by different transport systems. This delivery can either be done through road, railway or air. These are synonymous to the delivery systems used to implement building construction projects. The delivery of the projects like delivery of goods is done through various project delivery attributes. For example, the user involvement or participation on this matter is very important so that the right project that meet their needs is delivered. Resources in form of labor, raw materials and equipment are at the centre of the delivery of the building product. These are items that are affected by the procurement practices used by an organization from all stages of the supply chain. Study of use of alternative project delivery attributes rather than breadth of experience, empowerment, and cohesion as affecting the project success has been recommended (Marcus, Mark and Karen, 2010). Moreover, Debby, (2017) developed 39 performance attributes that are necessary during project implementation. The list included user involvement issues and procurement practices issues amongst others. This paper focused on evaluating the influence of user involvement on the implementation of building construction projects in the Kenyan Judiciary as moderated by the procurement practices.

\subsection{Research Objective}

The research objectives of this study were to assess the influence of user involvement on the implementation of building construction projects in the Kenyan Judiciary and examine the moderating influence of procurement practices on the relationship between user involvement and the implementation of building construction projects in the Kenyan Judiciary.

\subsection{Hypothesis}

The study sought to test the following hypotheses:

1. $\mathrm{H}_{0}$ : User Involvement has no significant relationship with implementation of construction projects in the Kenyan Judiciary.

1. $\mathrm{H}_{1}$ : User Involvement has significant relationship with implementation of construction projects in the Kenyan Judiciary.

2. $\mathrm{H}_{0}$ : There is no significant moderating influence of procurement practices on the relationship between User Involvement and implementation of construction projects in the Kenyan Judiciary.

2. $\mathrm{H}_{1}$ : There is a significant moderating influence of procurement practices on the relationship between User Involvement and implementation of construction projects in the Kenyan Judiciary.

\subsection{Literature Review}

This section covers the review of literature on user involvement and implementation of building construction projects, findings and the gaps that exist which this study sought to fill by answering the research questions posed so as to achieve the study objectives and resolve the study problem.

\subsection{User involvement and Implementation of Building Construction Projects}

Matende, Ogao and Nabukenya (2015) in their paper used a private university as a case study to examine the role played by user participation in the implementation of an ERP system. The study adopted a mixed method where both qualitative and quantitative approaches were used in the collection of data. The results of the study revealed that user participation has a positive impact on the likelihood of ERP system success. They concluded that user participation in ERP system implementation is critical for successful implementation of information systems (IS). Kujala, Kauppinen, Lehtola and Kojo (2005) reported on a result of interviews and survey conducted to investigate the role of user involvement in defining user requirements in development projects. The survey involved 18 software practitioners working in software related development projects in 13 companies in Finland. In addition, eight software practitioners working in three companies were interviewed. The study combined qualitative and statistical analysis to examine how users were involved in development projects and how user involvement influenced projects. The analysis showed that early user involvement is related to better requirements quality. The analysis also showed that involving users and customers as the source of information is related to project success.

Nyandika and Ngugi (2014) investigated the effect of stakeholder's participation on highway project performance. Although, the primary purpose was to investigate the effect of stakeholder's participation, user involvement, technology adoption, top management characteristics were also investigated on road construction project performance. Descriptive research design with a mix of both qualitative and quantitative approaches was adopted. A sample of 75 respondents were selected through simple random sampling. Data was analyzed through descriptive and inferential statistics. It was found that awareness, feasibility studies, conferences and seminars impacted positively on project performance. Moreover, information technology skills, computer aided designs 
and internet had positive impact on road project performance. Thirdly, top management had positive performance on road construction performance. Finally, acquisition of requisite skills impacted positively on road construction performance. It was concluded that there is need to create measures which are geared towards creating project awareness and encouraging participation in project related activities.

An investigation on critical success factors on project implementation was carried out by (Alias, Zawawi, Yusof \& Aris, 2014). The study hypothesed that project success is dependent on support from senior management, user capital skills, stakeholder's commitment, communication and feedback channels deployed, clear and detailed implementation of construction projects plan and availability of financial support. Descriptive research design was adopted. Structured questionnaires were applied to collect primary data. Content analysis was used to analyze the data. It was found that implementation of construction projects is dependent on project management actions, human factors, project factors and external environment. It was concluded that there is need to create relationships between internal and external stakeholders. Although, empirical studies have documented that there is a positive and significant relationship between project management process and user satisfaction (Serra and Kunc, 2015), implementation of construction projects is a process and cannot be purely evaluated from management perspective, it must adopt two faced approach. Consequently, the need to understand user characteristics since they will be project end users and their input ought to be continuously considered during project delivery.

While Project budgetary allocation is supposed to be competitive this has not been the case because some contractors are greed propelled and end up undervaluing projects to quench their desperation to win contracts (Oluwole, 2008). Owing to prevailing economic conditions, implementation of construction project is halted due to frequent cost revaluation which ends up escalating budgetary allocations. Users are also faulted on their contractor evaluation criteria and are blamed in most cases because of selecting lowest bidders. This has been blamed because of its short sighted, subjective and ignorance of value because it can only deliver standards which match its pricing quotations (Barbara, 2010). To alter this trend both user and contractors should be willing to share project risk, this will create win win contracting approach and subsequently enhance project value. Contractor evaluation criterion should also not only be cost guided but value driven too.

There is need for development of participatory approaches towards project management since all stakeholders agree that implementation of construction projects must yield better results as compared to the past (Dubois, Hanlon, Koch, Nyatuga and Kerr, 2016).In this study an examination of the importance of user's involvement in implementation of building construction projects in Kenyan Judiciary was done so as to devise measures in future which would ensure consultant and contractors in Kenyan Judiciary projects incorporates users' input and enhance quality and speed of project delivery.

\subsection{Methodology}

In this section, research methodology which was used to achieve objectives is presented

\subsection{Introduction}

The study adopted a mixed research methodology whereby both quantitative and qualitative approaches were used to collect and analyse data. A thorough literature review was carried out on implementation of building construction projects, project delivery systems and procurement practices with the aim of addressing the objectives of the study. The research instruments were constructed after the objectives were stated and hypothesis formulated. They were tested for validity and reliability. This process was guided by pragmatism paradigm design.

Quantitative and Qualitative data was collected from 127 respondents which represented 54\% response rate from Court User committee chair persons, Infrastructure committee members, clerk of works, Architects, Contractors, Quantity surveyors, Engineers and NEMA specialists.Quantitative data was collected from 108 respondents while Qualitative data was collected from 19 key informants (Project committee members and NEMA specialists). The researcher adhered to ethical issues inclusive of honesty and trust, voluntary participation, privacy, anonymity, disclosure, harm and risk policy.

\subsection{Pilot Test}

Data collection instruments were pilot tested on 30 respondents derived from 15 projects which were ongoing in Judiciary. According to Sekaran and Bougie (2013) pilot test is carried out to establish the validity, reliability and accuracy of a research instrument prior to its administration. Through piloting viability of a research design can be examined. Cooper and Schnidler (2014) recommended pilot testing so as to identify challenges which may hinder correct data collection and any hurdle which may create uneasiness amongst the respondents. Thus, piloting was carried out to examine the ability of the research instruments to solicit for data required in the study. From piloting unclear, vague and ambiguous questions were reframed, deleted and replaced with those that enhanced attainment of study objectives. The pilot study established that the questionnaire was valid and reliable 
for all the target respondents except the NEMA Specialist who indicated that they were not preview to some of the information sought in the quantitative study thus could not complete the questionnaire, as such, the researcher moved their sample to the qualitative study.

\subsection{Validity of Research Instruments}

Validity is the ability of the research instrument to achieve the measurement of the contents desired in the study (Sekeran and Bougie, 2013). Moreover, Cooper and Schnindler (2014) argued that validity is the ability of the research instrument to be truthful, accurate and meaningful in measuring what it was supposed to measure as per study objectives and research questions. In this study validity of research instruments was enhanced through examination of their content and face validity. Content validity was established through trio expatriate opinion all hailing from University of Nairobi and they determined whether contents in the questionnaire captured the study contents. This was in tandem with recommendations by Cooper and Schindler (2014), that a three-judge bench comprising experts from an area under investigation can determine the accuracy of a research instrument.

To attain face validity, the research instruments were distributed amongst three independent project management experts who were tasked to scrutinize the research instruments to examine their contents in relation to study objectives. The feedback from the experts were incorporated in the research instruments prior to their distribution

\subsection{Reliability of the Research Instruments}

Reliability is the ability of a research instrument to yield consistent results when administered on similar respondents at different times (Bryman and Bell, 2015). Further, Copper and Schindler (2014) argued that reliability is determined by the extent to which research instruments give similar results when administered on different respondents hailing from a similar population. Questionnaires were administered on court user committee chair persons, project managers, engineers, contractors' foremen, quantity surveyors and NEMA specialists drawn from 30 JPIP and 33 GOK projects. Cronbach Alpha was used to test for reliability. Alpha values (coefficients) range from zero (0) where there is no internal consistency to one (1) where there is total internal consistency. The higher the coefficient, the more reliable the measurements scale.The alpha coefficient was 0.862 which was greater than 0.7 a figure considered reliable.

\subsection{Data Collection Procedure}

Research introduction letter was sought from University of Nairobi. The letter was instrumental in applying for research permit from National Commission for Science, Technology and Innovation (NACOSTI), which was presented to the Kenyan Judiciary to get approval to collect data from completed and ongoing construction projects. The researcher administered questionnaires with the help of research assistants who understood the status of completed and ongoing construction projects. The Questionnaire was scripted online on Kobo Toolbox platform, thereafter, Computer Aided Personal Interviews (CAPI) were conducted where an interactive link was sent to the target respondents for them to fill the questionnaire, after which, they submitted the data to a cloud server, where the data was accessed and analyzed. This method was ideal given the prevailing COVID-19 situation in Kenya during the data collection period. The data was collected during the month of August, 2020.

\section{Results}

This section presents data analysis, results and discussions based on field-data collected from the targeted study participants. The findings presented formed a basis for drawing conclusions and recommendations for the study.

\subsection{Demographic profiles of respondents}

Demographic details of the respondents comprising role in project, gender of respondents, education level and duration of service in the project are presented in Table 1.The study was based on the whole population (census) and so the selection of respondents was not randomized. The respondents distribution was appropriate as all groups were well represented. 
Table 1: Demographic profiles of respondents

\begin{tabular}{|c|c|c|}
\hline \multicolumn{3}{|l|}{ Role in the Project. } \\
\hline Respondents & Frequency(f) & Percentage $\%$ \\
\hline CUC Chairperson/HoS & 30 & $24 \%$ \\
\hline Contractor Foreman & 30 & $24 \%$ \\
\hline Clerk of Works & 18 & $14 \%$ \\
\hline Engineers & 15 & $12 \%$ \\
\hline NEMA Specialists & 11 & $9 \%$ \\
\hline Architects & 9 & $7 \%$ \\
\hline $\mathrm{ICM}$ & 8 & $6 \%$ \\
\hline Quantity Surveyors & 6 & $5 \%$ \\
\hline Total & 127 & 100 \\
\hline \multicolumn{3}{|l|}{ Gender of Respondents } \\
\hline Gender & Frequency(f) & Percentage $\%$ \\
\hline Male & 93 & $86 \%$ \\
\hline Female & 15 & $14 \%$ \\
\hline Total & 108 & 100.0 \\
\hline \multicolumn{3}{|c|}{ Highest Level of Education - (Quantitative Study) } \\
\hline Education Level & Frequency(f) & Percentage $\%$ \\
\hline Undergraduate degree & 68 & $63 \%$ \\
\hline Postgraduate degree & 25 & $23 \%$ \\
\hline Diploma/ Certificate & 15 & $14 \%$ \\
\hline Total & 108 & 100 \\
\hline \multicolumn{3}{|l|}{ Duration of service in the Project } \\
\hline Respondents duration of service & Frequency(f) & Percentage $\%$ \\
\hline Less than 3 years & 28 & $26 \%$ \\
\hline Between 5 and 3 years & 31 & $29 \%$ \\
\hline Above 5 years & 49 & $45 \%$ \\
\hline Total & 108 & 100 \\
\hline
\end{tabular}

From table 1 majority of the respondents (60;48\%) were CUC Chairperson/Hos (Head of Stations) and Contractor's Foremen, followed by Clerk of works and Engineers (33; 26\%). NEMA Specialists, Architects, Infrastructure committee members, (ICM) and Quantity Surveyors.This distribution is significant since the Court User Committee chair persons and clerk of works who are the majority respondents were on sites on daily basis thus their response on the project questionnaires were likely to be accurate. In addition the respondents like CUC (Head of Stations) NEMA specialist, Architects, Engineers, Infrastructure Committee members and Quantity Surveyors are conversant with the projects as they participated in designs and project supervision.

While majority of the respondents were male $(93 ; 86 \%)$ while only $15(14 \%)$ were female, implying that implementation of construction projects in the Kenyan Judiciary is male dominated. This is in line with other studies done in the construction industry. BORAQS (2012) found out that, women professionals in the industry accounted for only $6 \%$ of the construction industry professionals while National Construction Authority (2014) noted that women were underrepresented in the construction industry comprising of only $19 \%$ of employment with only $7 \%$ of them owning construction contracting firms.

Majority of the respondents $(68 \%$ or $63 \%$ ) also had first degree and postgraduate degrees (25or $23 \%$ ) while $15(14 \%)$ had Diploma/ Certificate after completion of form four. With all the respondents having tertiary college level of education and above it was expected that they were aware of the project requirements.

In addition majority of the respondents had more than 3 years' of service in the project $(80 ; 74 \%)$ and only $(28 ; 26 \%)$ had worked in the project for less than 3 years'. This shows that most of the respondents had enough experience in the projects they were managing and could therefore ably respond to individual projects questionnaires.

\subsection{Description of user involvement from Likert Scale Data}

The aggregated scores were inserted under the individual scales as rated by the respondents. The responses are as shown in table 2 
Table 2;Description of user involvement likert scale data

\begin{tabular}{|c|c|c|c|c|c|c|}
\hline & Statement & $\mathbf{N}$ & Min & Max & $\begin{array}{l}\text { Mean } \\
\text { (M) }\end{array}$ & $\begin{array}{l}\text { Std Deviation } \\
\text { (SD) }\end{array}$ \\
\hline 1.0 & Design stage & & & & & \\
\hline 1.1 & Preparation of feasibility study report. & 108 & 1 & 5 & 3.67 & 1.01 \\
\hline 1.2 & Development of guidelines on stakeholder involvement. & 108 & 1 & 5 & 3.81 & 0.97 \\
\hline 1.3 & Guidelines for project manager. & 108 & 1 & 5 & 3.94 & 0.85 \\
\hline \multirow[t]{2}{*}{1.4} & Development of project plan. & 108 & 1 & 5 & 3.84 & 0.90 \\
\hline & & 108 & 1 & 5 & 3.82 & 0.79 \\
\hline 2.0 & Construction Supervision, & & & & & \\
\hline 2.1 & $\begin{array}{l}\text { Supervision was done monthly by the project } \\
\text { implementation team }\end{array}$ & 108 & 1 & 5 & 4.31 & 1.00 \\
\hline 2.2 & Time management tools are used & 108 & 1 & 5 & 3.86 & 1.11 \\
\hline 2.3 & Cost management tools are used & 108 & 1 & 5 & 3.83 & 1.16 \\
\hline \multirow[t]{2}{*}{2.4} & $\begin{array}{l}\text { Contract administration is done well by Contract } \\
\text { implementation team. }\end{array}$ & 108 & 1 & 5 & 4.11 & 0.87 \\
\hline & & 108 & 1 & 5 & 4.03 & 0.88 \\
\hline 3.0 & Inspection and certification of the works. & & & & & \\
\hline 3.1 & $\begin{array}{l}\text { Works are timely certified by the Consultant or directorate } \\
\text { of building and services team. }\end{array}$ & 108 & 1 & 5 & 4.13 & 1.00 \\
\hline 3.2 & $\begin{array}{l}\text { The users are comfortable with chairing the inspection and } \\
\text { acceptance committees for certifiying works }\end{array}$ & 108 & 1 & 5 & 4.07 & 1.07 \\
\hline 3.3 & There are no delays in honouring of certificates & 108 & 1 & 5 & 3.64 & 1.14 \\
\hline \multirow[t]{2}{*}{3.4} & $\begin{array}{l}\text { Contractors payment requests are accurate concerning work } \\
\text { done on site. }\end{array}$ & 108 & 1 & 5 & 2.55 & 1.24 \\
\hline & & 108 & 1 & 5 & 3.60 & 0.61 \\
\hline 4.0 & Approval and Funding of the works & & & & & \\
\hline 4.1 & $\begin{array}{l}\text { There were no difficulties in getting World Bank approvals } \\
\text { to begin works on site. }\end{array}$ & 108 & 1 & 5 & 2.42 & 0.91 \\
\hline 4.2 & Funding of the projects had no challenges & 108 & 1 & 5 & 2.83 & 1.18 \\
\hline 4.3 & $\begin{array}{l}\text { Client and user approvals are obtained on time on every } \\
\text { project issue. }\end{array}$ & 108 & 1 & 5 & 3.51 & 1.04 \\
\hline \multirow[t]{3}{*}{4.4} & $\begin{array}{l}\text { There were no difficulties in getting Government of Kenya } \\
\text { approvals to begin works on site. }\end{array}$ & 108 & 1 & 5 & 2.61 & 1.06 \\
\hline & & 108 & 1 & 5 & 2.84 & 0.63 \\
\hline & & & & & 3.57 & 0.56 \\
\hline
\end{tabular}

Table 2 indicates that the majority of the respondents agreed that users were involved and participated in the design stage (process) during the implementation of building construction projects in the Kenyan Judiciary. Within the same indicator the respondents agreed that feasibility study report was prepared, guidelines on stakeholder involvement were developed, the guidelines for project manager were developed and Project plan was developed in consultation with stakeholders.

Majority of the respondents further agreed that users were involved or participated in construction supervision during the implementation of building construction projects in the Kenyan Judiciary. Within the same indicator the respondents were in agreement that Supervision was done monthly by the project implementation team, time management tools were used, cost management tools were used and contract administration was done well by Contract implementation team.

In addition the majority of the respondents agreed that the users were involved in inspection and certification of the works during the implementation of building projects in the Kenyan Judiciary. Within the same indicator the respondents agreed that works were timely certified by the Consultant or directorate of building and services team, the users were comfortable with chairing the inspection and acceptance committees for certifying works and that there were no delays in honoring of certificates. The respondents were however undecided that contractors payment requests were accurate concerning work done on site.

On the other hand majority of the respondents were undecided that users were involved in the approval and funding of the works in the implementation of building construction projects in the Kenyan Judiciary. Within the same indicator the respondents disagreed that there were no difficulties in getting World Bank approvals to begin works on site were undecided that funding of the projects had no challenges, respondents agreed that the client and user approvals were obtained on time on every project issue but disagreed that there were no difficulties in getting Government of Kenya approvals to begin works on site. 
Overall, majority of the respondents agreed that there was user involvement during the implementation of building construction projects in the Kenyan Judiciary. The respondents ranked the indicators from the highest to the lowest as follows; Construction Supervision, Design Stage, Inspection and Certification of the Works and lastly Approval and Funding of Works. Results obtained from interviews, focus group discussions and document content analysis indicated that there was user involvement during the implementation of building construction projects in the Kenyan Judiciary.

\subsection{Inferential Analysis}

Further examination using Pearson's correlation analysis was done to establish the direction and strength of the relationship between User involvement and implementation of construction projects. Linear regression analysis was then used to test the second hypothesis of the study which was stated as follows:

$1 H_{0}$ : User involvement has no significant relationship with implementation of building construction projects in Kenyan Judiciary.

$1 H_{1}$ : User involvement has significant relationship with implementation of building construction projects in Kenyan Judiciary.

The results are presented in Table 3

Table 3: Results of correlation and hypothesis test of User involvement on Implementation of Building Construction Projects

Correlation analysis results on User Involvement

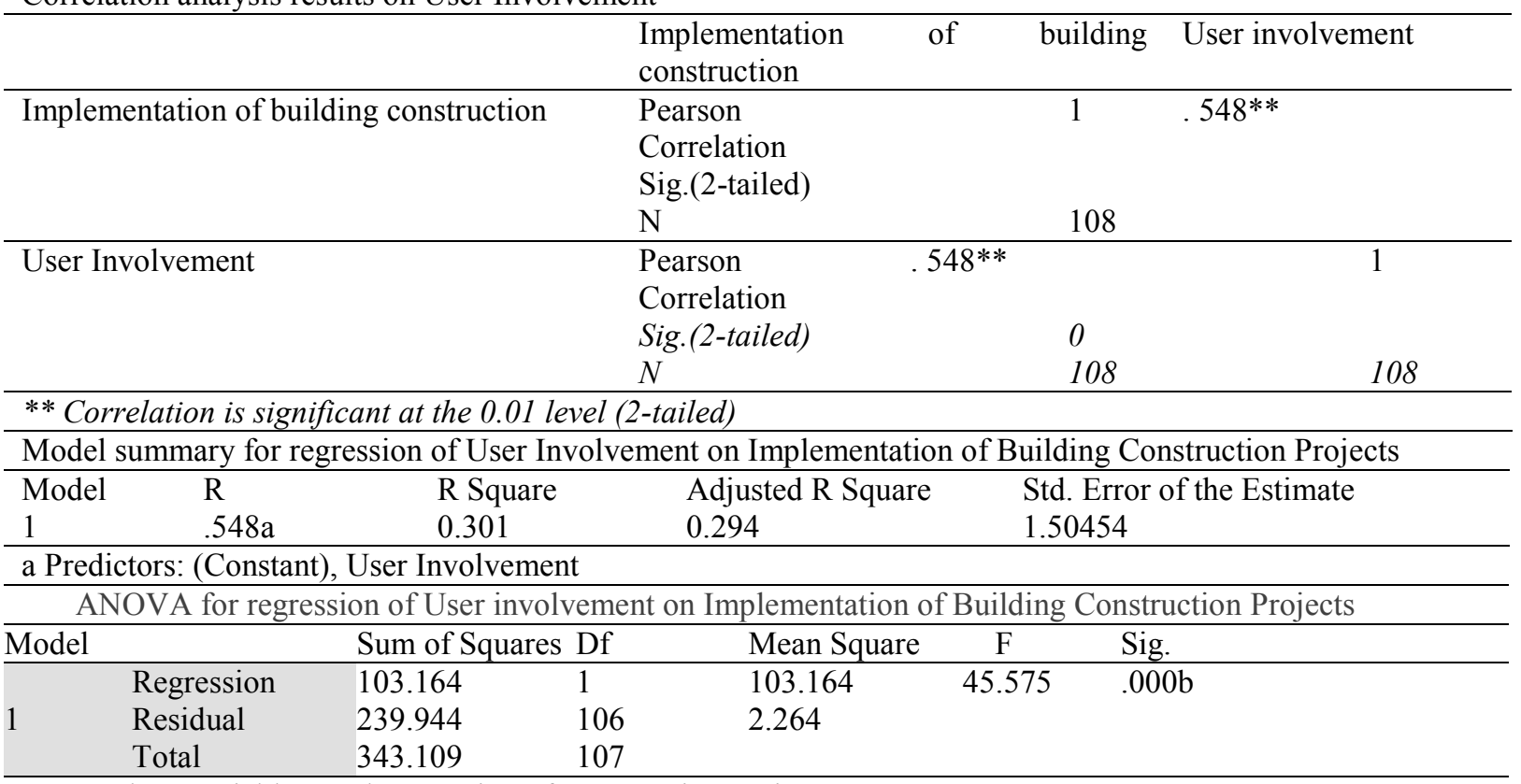

a. Dependent Variable: Implementation of construction projects

b. Predictors: (Constant): User Involvement Coefficients of Regression of User Involvement on Implementation of Building Construction Projects

\begin{tabular}{|c|c|c|c|c|c|c|}
\hline \multirow{2}{*}{\multicolumn{2}{|c|}{ Model }} & \multicolumn{2}{|c|}{ Unstandardized Coefficients } & $\begin{array}{l}\text { Standardized } \\
\text { Coefficients }\end{array}$ & \multirow[t]{2}{*}{$\mathrm{T}$} & \multirow[t]{2}{*}{ Sig. } \\
\hline & & $\mathrm{B}$ & Std. Error & Beta & & \\
\hline \multirow[t]{2}{*}{1} & (Constant) & 3.104 & 0.568 & & 5.466 & 0 \\
\hline & User Involvement & 0.489 & 0.072 & 0.548 & 6.751 & 0 \\
\hline
\end{tabular}
a. Dependent Variable: Implementation of Judiciary construction projects

The results from Table 3 indicate that User involvement has positive and significant relationship with implementation of building construction projects with $\beta=0.548$ ( $\mathrm{t}=6.751, \mathrm{p}=0<0.01 ; 2$-tailed). This suggested that user involvement could have an influence on implementation of building construction projects in the Kenyan Judiciary.

The coefficient of determination $\mathrm{R}^{2}=0.301$. This means that $30.1 \%$ of the variance in implementation of construction projects in the Kenyan Judiciary was explained by user involvement

ANOVA results show that the F-calculated $(\mathrm{F}=45.575)$ was greater than F-critical (3.94), with $\mathrm{p}=0.00<0.05$. The regression model was therefore a good fit for the data analyzed and may be used for predicting 
Implementation of Building Construction projects in the Kenyan Judiciary.

The null hypothesis that user involvement has no significant influence on implementation of building construction projects in Kenyan Judiciary was rejected and the alternative accepted that user involvement has a significant influence on implementation of building construction projects in Kenyan Judiciary. Implementation of Building Construction projects "Y" can be predicted, in part, by

User Involvement " $\mathrm{X}$ " using the model $\mathrm{Y}=3.104+0.489 \mathrm{X}_{1}$ From Table 3,

Where: Y - Implementation of building Construction Projects.

$\mathrm{X}_{1}$ - User Involvement.

This study findings are in line with other studies (Lim and Ling, 2002; Al Khalil, 2002) that observed that clients' involvement in construction project has a positive effect on success of a project. This is also consistent with the findings from previous study by Poon et.(2000) who indicated that user involvement needs to be high and running across the different phases of the project for better project performance.

\subsection{Moderating influence of Procurement Practices on the relationship between User involvement and} implementation of the building construction projects in the Kenyan Judiciary

Further examination using Pearson's correlation analysis was done to establish the direction and strength of the relationship between User involvement and implementation of construction projects. Linear regression analysis was then used to test the second hypothesis of the study which was stated as follows:

2.H $H_{0}$ : There is no significant moderating influence of procurement practices on the relationship between User Involvement and implementation of construction projects in the Kenyan Judiciary.

2. $H_{1}$ : There is a significant moderating influence of procurement practices on the relationship between User Involvement and implementation of construction projects in the Kenyan Judiciary.

Table 4: Results of correlation and hypothesis test of moderated User involvement on Implementation of Building Construction Projects

Correlation analysis results on moderated user involvement.

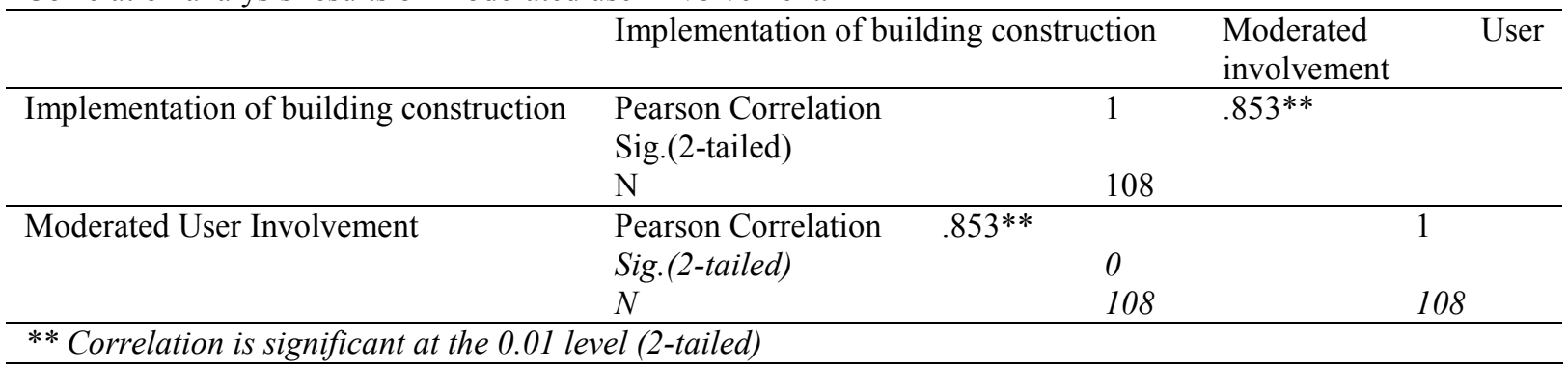

Model summary for regression of Moderated User Involvement on Implementation of Building Construction Projects

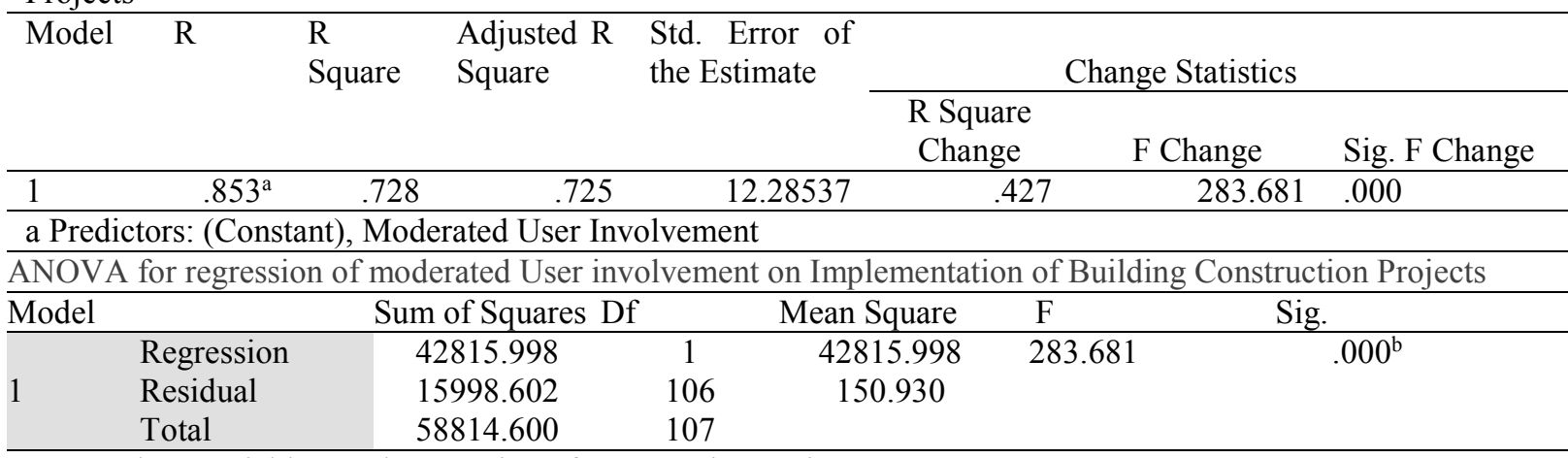

a. Dependent Variable: Implementation of construction projects

b. Predictors: (Constant): moderated User Involvement

Coefficients of Regression of Moderated User Involvement on Implementation of Building Construction Projects

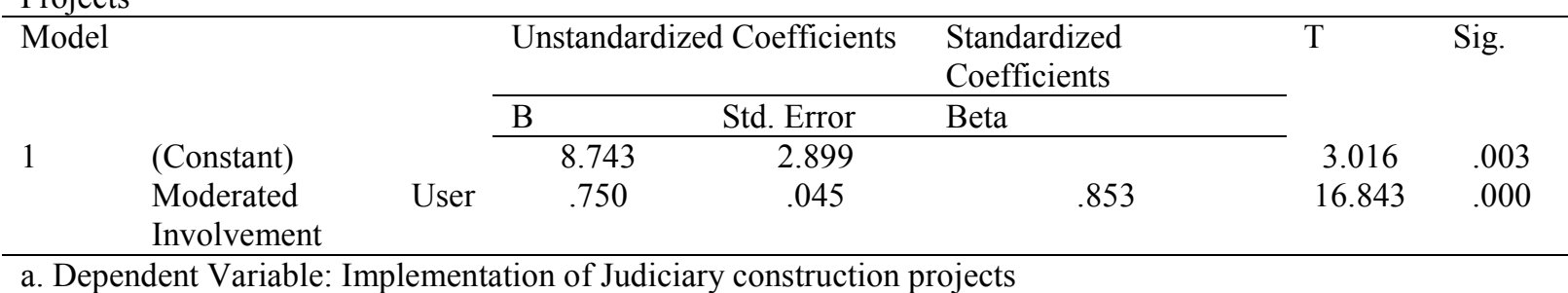


From Table 4.the coefficient of determination $\mathrm{R}^{2}=0.728$. This means that $72.8 \%$ of the variance in implementation of construction projects in the Kenyan Judiciary was explained by moderated user involvement. The procurement practices moderated the relationship between project team integration and implementation of building construction projects with $\mathrm{R}^{2}$ Change $=\mathbf{0 . 4 2 7}(\mathbf{p}=\mathbf{. 0 0 0}<\mathbf{0 . 0 5})$. The null hypothesis that there is no significant moderating influence of procurement practices on the relationship between user involvement and implementation of building construction projects in Kenyan Judiciary was rejected and alternative hypothesis that there is a significant moderating influence of procurement practices on the relationship between user involvement and implementation of building construction projects in Kenyan Judiciary accepted.

ANOVA results show that the F-calculated $(F=283.681)$ was greater than F-critical $(3.94)$, with $p=0.00<$ 0.05. The regression model was therefore a good fit for the data analyzed and may be used for predicting Implementation of Building Construction projects in the Kenyan Judiciary.

Implementation of Building Construction projects " $\mathrm{Y}$ " can be predicted, in part, by Project delivery systems " $\mathrm{X}$ " using the model $\mathrm{Y}=\mathrm{Y}=3.104+0.489 \mathrm{X}_{1}+0.75 \mathrm{X}_{2}$ From Table 3 and 4 , Where: $\mathrm{Y}$ - Implementation of building Construction Projects.

$\mathrm{X}_{1}$-User involvement, and

$\mathrm{X}_{2}$ - moderated user involvement.

\section{Conclusions}

The first objective assessed the influence of user involvement on the implementation of building construction projects in Kenyan Judiciary. The study sought to measure User's involvement in the design process, supervision of the construction, inspection and certification of works, and approval and funding of works. The study findings indicate that User involvement significantly influence the implementation of building construction projects in Kenyan Judiciary. The study concludes that User involvement significantly influence implementation of building Construction projects.

Finally, the second objective examined the moderating influence of procurement practices on the relationship between user involvement and the implementation of building construction projects in Kenyan Judiciary. The results indicated that there was a significant moderating influence of procurement practices on the relationship between user involvement and the implementation of building construction projects in Kenyan Judiciary. The study concludes that project procurement practices significantly influence the relationship between User involvement and the implementation of building construction projects.

\section{Recommendations}

This section presents recommendations according to the two objectives of the study and areas for further research. The first set of recommendations is made for practitioners in project management while the second set is for policy intervention. The last set of recommendations are addressed to Scholars of Project Management.

The study established that user involvement has a significant influence on implementation of building construction projects in Kenyan Judiciary and that $30.1 \%$ of the variance in implementation of construction projects in the Kenyan Judiciary was explained by User Involvement. The study has thus revealed that User Involvement is one of the key success factors in implementation of building construction projects and should be given attention by Project management practitioners during project implementation.

The Judiciary can improve on the implementation of its building construction projects by closely monitoring and carrying out the best industry practices on the indicated user involvement attributes.

This study is beneficial to public sector organizations, project sponsors or patrons, investors in infrastructure projects, contractors, consultants, the domestic and international lending institutions and agencies including other governmental and non-governmental organizations interested in infrastructure projects as it provides them with information on user involvement as one of the project delivery attributes required for successful implementation of building construction projects in Kenya and developing countries with similar issues to Kenya.

The study has used system theory and introduced a new way of looking at project delivery in terms of a transport system where a project just like goods can be delivered by road, railways or air. The delivery of the projects just like the delivery of goods is done through various project delivery attributes e.g the user involvement on the process and the procurement practices used.

The study has found significant influence of user involvement on the implementation of building construction projects albeit in a developing country. Amongst these factors will be some that the author refer to as product production or manufacture factors. The delivery system can affect the quality of a product by making sure that it delivers the manufactured good without damages but if the manufactured good is defective from the factory (Contractors team) the delivered project will be defective whatever system is used. There is need to develop this model so as to isolate and control contractors construction activities as this is key to project delivery. The attributes assessing contractors construction success need to be included in the project delivery attributes 
model.

Procurement practices is one of the key success factors that need to be properly managed in the study of the relationship between user involvement and implementation of building construction projects as it enhances that relationship.Similar studies could also be done in other organizations ( e.g ministry of education projects, Ministry of health projects within the Central and County Governments) implementing building construction projects to enable comparison and development of best practices relevant to Kenya or any developing Country.

\section{REFERENCES}

Alias, Z., Zawawi, E. M. A., Yusof, K., \& Aris, N. M., (2014). Determining Critical Success Factors of Project Management Practice: A conceptual framework, Procedia - Social and Behavioral Sciences, 153(14):61 69.

Barbara, D., (2010). Critical success factors for developmental team projects, team performance management: An International Journal, 16(8), 343-358.

Bryman, A., \& Bell, E. (2015). Business research methods. (4 ${ }^{\text {th }}$ Ed.) Upple. Malmö: Liber AB.

Cooper, D. R., \& Schindler, P. S. (2014). Business research methods. (12 ${ }^{\text {th }}$ Ed.). New York: McGraw-Hill/Irwin

Debby, W, (2017). Developing attributes for evaluating construction project-based performance, The TQM Journal, 29(2):369-384.

Deloitte (2017). A shift to more but less Africa construction trends. Retrieved from https://www2.deloitte.com

Dubois, M., Hanlon, J., Koch, J., Nyatuga, B. \& Kerr, J. (2016). Leadership styles of project managers: Techniques and traits to lead high performance teams, Journal of Economic Development, Management, IT, Finance and Marketing, 7(1):30-46.

Ika, L. A., Diallo, A., and Thuillier, A. D. (2010)."Project management in the international development industry: The project coordinator's perspective", International Journal of Managing Projects in Business, 3(1):61-93.

Ika, L. A., Diallo, A., \& Thuillier, A. D. (2012).Critical success factors for World Bank projects: An empirical investigation. International Journal of Project Management, 30(1):105-116.

Kujala S.,Kauppinen M.,Lehtola L. and Kojo T., (2005). The role of user involvement in requirements quality and project success Conference: Requirements Engineering, 2005. Proceedings. 13th IEEE International Conference .

Marcus A. R., Mark, S, \& Karen, J. G., (2010). The impact of project team attributes on ERP system implementations: A positivist field investigation, Information Technology \& People,23(1):80-109.

Muller, R., Geraldi, J., \& Turner, J. R. (2012). Relationships between leadership and success in different types of project complexities, Transactions of Engineering management, 59(1):77-88.

Matende S.,Ogao P. \& Nabukenya J., (2015).User participation in ERP Implementation: A Case-based Study International Journal of Computer Applications Technology and Research. 4(1): 24 - 29, 2015, ISSN:2319-8656.

Nyandika, O. F \& Ngugi, K. (2014). Influence of Stakeholders' Participation on Performance of Road Projects at Kenya National Highways Authority, European Journal of Business Management,1(11):384-404.

Ochieng, E. G., \& Price, A. D. (2009). Framework for managing multicultural project teams, Engineering, construction and Architectural Management, Journal of Construction Management, 16(6):527-543.

Oluwole A. O., (2008). A comparative analysis of tender sums and final costs of public construction and supply projects in Nigeria, Journal of Financial Management of Property and Construction, 13(1):60-79.

Serra, Carlos Eduardo Martins \& Kunc, Martin (2015). Benefits Realisation Management and its influence on project success and on the execution of business strategies, International Journal of Project Management, 2015.Vol. 33 